\title{
Indications of nitrogen-limited methane uptake in tropical forest
}

\section{soils}

\author{
E. Veldkamp ${ }^{1}$, B. Koehler ${ }^{2}$, and M. D. Corre ${ }^{1}$ \\ ${ }^{1}$ Soil Science of Tropical and Subtropical Ecosystems, Buesgen Institute, Georg-August-Universität Göttingen, \\ Buesgenweg 2, 37077 Göttingen, Germany \\ ${ }^{2}$ Department of Limnology, Evolutionary Biology Centre, Uppsala University, Norbyvägen 18 D, 75236 Uppsala, Sweden
}

Correspondence to: E. Veldkamp (eveldka@gwdg.de)

Received: 14 March 2013 - Published in Biogeosciences Discuss.: 28 March 2013

Revised: 19 June 2013 - Accepted: 21 June 2013 - Published: 9 August 2013

\begin{abstract}
It is estimated that tropical forest soils contribute $6.2 \mathrm{Tg} \mathrm{yr}^{-1}(28 \%)$ to global methane $\left(\mathrm{CH}_{4}\right)$ uptake, which is large enough to alter $\mathrm{CH}_{4}$ accumulation in the atmosphere if significant changes would occur to this sink. Elevated deposition of inorganic nitrogen $(\mathrm{N})$ to temperate forest ecosystems has been shown to reduce $\mathrm{CH}_{4}$ uptake in forest soils, but almost no information exists from tropical forest soils even though projections show that $\mathrm{N}$ deposition will increase substantially in tropical regions. Here we report the results from two long-term, ecosystem-scale experiments in which we assessed the impact of chronic $\mathrm{N}$ addition on soil $\mathrm{CH}_{4}$ fluxes from two old-growth forests in Panama: (1) a lowland, moist (2.7 $\mathrm{m} \mathrm{yr}^{-1}$ rainfall) forest on clayey Cambisol and Nitisol soils with controls and $\mathrm{N}$-addition plots for 9$12 \mathrm{yr}$, and (2) a montane, wet (5.5 $\mathrm{m} \mathrm{yr}^{-1}$ rainfall) forest on a sandy loam Andosol soil with controls and $\mathrm{N}$-addition plots for 1-4 yr. We measured soil $\mathrm{CH}_{4}$ fluxes for $4 \mathrm{yr}$ (2006-2009) in four replicate plots $(40 \mathrm{~m} \times 40 \mathrm{~m}$ each) per treatment using vented static chambers (four chambers per plot). $\mathrm{CH}_{4}$ fluxes from the lowland control plots and the montane control plots did not differ from their respective $\mathrm{N}$-addition plots. In the lowland forest, chronic $\mathrm{N}$ addition did not lead to inhibition of $\mathrm{CH}_{4}$ uptake; instead, a negative correlation of $\mathrm{CH}_{4}$ fluxes with nitrate $\left(\mathrm{NO}_{3}^{-}\right)$concentrations in the mineral soil suggests that increased $\mathrm{NO}_{3}^{-}$levels in $\mathrm{N}$-addition plots had stimulated $\mathrm{CH}_{4}$ consumption and/or reduced $\mathrm{CH}_{4}$ production. In the montane forest, chronic $\mathrm{N}$ addition also showed negative correlation of $\mathrm{CH}_{4}$ fluxes with ammonium concentrations in the organic layer, which suggests that $\mathrm{CH}_{4}$ consumption was $\mathrm{N}$ limited. We propose the following reasons why such $\mathrm{N}$-stimulated $\mathrm{CH}_{4}$ consumption did not lead to sta-
\end{abstract}

tistically significant $\mathrm{CH}_{4}$ uptake: (1) for the lowland forest, this was caused by limitation of $\mathrm{CH}_{4}$ diffusion from the atmosphere into the clayey soils, particularly during the wet season, as indicated by the strong positive correlations between $\mathrm{CH}_{4}$ fluxes and water-filled pore space (WFPS); (2) for the montane forest, this was caused by the high WFPS in the mineral soil throughout the year, which may not only limit $\mathrm{CH}_{4}$ diffusion from the atmosphere into the soil but also favour $\mathrm{CH}_{4}$ production; and (3) both forest soils showed large spatial and temporal variations of $\mathrm{CH}_{4}$ fluxes. We conclude that in these extremely different tropical forest ecosystems there were indications of $\mathrm{N}$ limitation on $\mathrm{CH}_{4}$ uptake. Based on these findings, it is unlikely that elevated $\mathrm{N}$ deposition on tropical forest soils will lead to a rapid reduction of $\mathrm{CH}_{4}$ uptake.

\section{Introduction}

Methane $\left(\mathrm{CH}_{4}\right)$ is an important atmospheric trace gas because it influences both the energy and the oxidant balance of the earth's atmosphere. Presently, the atmospheric concentration of $\mathrm{CH}_{4}$ is about $1800 \mathrm{ppbv}$, which accounts for about $0.48 \mathrm{~W} \mathrm{~m}^{-2}$ of the total anthropogenic radiative forcing (Denman et al., 2007). About $75 \%$ of the global $\mathrm{CH}_{4}$ source strength, which is about $600 \mathrm{Tg} \mathrm{yr}^{-1}$, originates from biogenic sources wherein $\mathrm{CH}_{4}$ is exclusively produced by methanogenic microorganisms (Conrad, 1989). Although $\mathrm{CH}_{4}$ is primarily produced in wetland soils, $\mathrm{CH}_{4}$ production can also occur in upland soils during high rainfall or wet season, for example in anaerobic microsites inside soil 
aggregates (Keller and Reiners, 1994). In well-aerated soils, $\mathrm{CH}_{4}$ is oxidized by methanotrophic microorganisms and $\mathrm{CH}_{4}$ oxidation normally exceeds production, which results in a net $\mathrm{CH}_{4}$ uptake. The largest biogenic sink of atmospheric $\mathrm{CH}_{4}$ is through uptake by upland soils, which contributes about $5 \%$ to the total removal of $\mathrm{CH}_{4}$ from the atmosphere (Reeburgh, 2003).

Tropical ecosystems play an important role in the production and uptake of atmospheric $\mathrm{CH}_{4}$ (Keller and Matson, 1994). In tropical forest areas, known wetland sources of $\mathrm{CH}_{4}$ production do not suffice to explain the observed high $\mathrm{CH}_{4}$ concentrations over Neotropical forests (Frankenberg et al., 2008), and some "canopy" wetlands may contribute significantly to the $\mathrm{CH}_{4}$ production (Martinson et al., 2010). Most tropical forests grow on well-drained upland soils that are too dry to emit $\mathrm{CH}_{4}$ but act instead as an important sink for atmospheric $\mathrm{CH}_{4}$ (Kiese et al., 2003). In a review where measurements were stratified according to climatic zone, ecosystem and soil texture, the total global $\mathrm{CH}_{4}$ uptake was estimated at $22.4 \mathrm{Tg} \mathrm{yr}^{-1}$, of which $9.2 \mathrm{Tg} \mathrm{yr}^{-1}$ $(41 \%)$ occurred in tropical ecosystems (Dutaur and Verchot, 2007). The contribution of tropical forest soils to global $\mathrm{CH}_{4}$ uptake was estimated at $6.2 \mathrm{Tg} \mathrm{yr}^{-1}(28 \%)$, which is large enough to alter the $\mathrm{CH}_{4}$ accumulation in the atmosphere if significant changes would occur to this sink.

$\mathrm{CH}_{4}$ fluxes at the soil surface are the result of methanogenesis and $\mathrm{CH}_{4}$ oxidation, which can occur simultaneously in aerated soils (Yavitt et al., 1995). The microorganisms involved in $\mathrm{CH}_{4}$ oxidation are methanotrophic bacteria and ammonium-oxidizing bacteria. Most methanotrophic bacteria use $\mathrm{CH}_{4}$ as their only source of carbon and energy and all use methane monooxygenase in the first step of $\mathrm{CH}_{4}$ oxidation (Hanson and Hanson, 1996). Methanotrophic bacteria are separated into Type I and II according to their biochemical pathways of oxidizing $\mathrm{CH}_{4}$. Type I methanotrophs are generally non-N-fixing organisms, while Type II methanotrophs can fix atmospheric $\mathrm{N}_{2}$ but can also assimilate mineral N (Hanson and Hanson, 1996). Depending on the $\mathrm{CH}_{4}$ concentration that they live on, two groups of methanotrophs can be distinguished: one group contains "low affinity" methanotrophs which are adapted for growth at high $\mathrm{CH}_{4}$ concentrations (e.g. in rice fields), and the other group contains "high affinity" methanotrophs which are able to make use of the atmospheric $\mathrm{CH}_{4}$ concentrations (around $1.8 \mathrm{ppm}$ ). Ammonium-oxidizing bacteria can also oxidize $\mathrm{CH}_{4}$ through the enzyme ammonia monooxygenase, which can react with $\mathrm{CH}_{4}$ instead of $\mathrm{NH}_{4}^{+}$(Bédard and Knowles, 1989).

The increased use of nitrogen $(\mathrm{N})$ fertilizers, fossil fuel, and cultivation of $\mathrm{N}$-fixing crops have more than doubled the amount of "reactive" nitrogen $\left(\mathrm{N}_{\mathrm{r}}\right)$ cycling worldwide (Vitousek et al., 1997). In the past decades, this has led to enhanced $\mathrm{N}_{\mathrm{r}}$ input in forest ecosystems, especially in economically developed regions of the temperate zone. Projections are that the input of $\mathrm{N}_{\mathrm{r}}$ will increase substantially in tropical regions such as Southeast Asia and South and Cen- tral America due to increasing agricultural and industrial use of N (Galloway et al., 2008). A recent study suggested that elevated anthropogenic $\mathrm{N}_{\mathrm{r}}$ deposition is probably already widespread in tropical forests (Hietz et al., 2011).

Elevated depositions of mineral $\mathrm{N}$ (ammonium $\left(\mathrm{NH}_{4}^{+}\right)$and nitrate $\left(\mathrm{NO}_{3}^{-}\right)$) and $\mathrm{N}$ fertilization to forest ecosystems have been shown to affect $\mathrm{CH}_{4}$ fluxes from forest soils (Steudler et al., 1989; Brumme and Borken, 1999). Several mechanisms have been proposed to explain how mineral $\mathrm{N}$ affects $\mathrm{CH}_{4}$ fluxes in upland soils. Most commonly, the inhibition of $\mathrm{CH}_{4}$ oxidation in the soil by increased $\mathrm{NH}_{4}^{+}$levels is mentioned, not only in temperate soils (Steudler et al., 1989; Crill et al., 1994) but also in tropical soils (Veldkamp et al., 2001). The enzyme methane monooxygenase, which initiates the oxidation pathway of $\mathrm{CH}_{4}$, is also able to oxidize $\mathrm{NH}_{4}^{+}$. When $\mathrm{NH}_{4}^{+}$competes with $\mathrm{CH}_{4}$ for reactive sites of methane monooxygenase, this can cause inhibition of $\mathrm{CH}_{4}$ oxidation (Bédard and Knowles, 1989).

An osmotic effect may also contribute to the inhibition of $\mathrm{CH}_{4}$ oxidation (Nesbit and Breitenbeck, 1992; Veldkamp et al., 2001). There is a discrepancy in published literature about the duration over which $\mathrm{NH}_{4}^{+}$can inhibit $\mathrm{CH}_{4}$ oxidation. An inhibition effect of $\mathrm{NH}_{4}$ for $13 \mathrm{yr}$ has been reported (Mosier et al., 1996), whereas in another study inhibition lasted only about four weeks (Veldkamp et al., 2001). On the other hand, increased $\mathrm{NO}_{3}^{-}$levels can inhibit $\mathrm{CH}_{4}$ production because $\mathrm{NO}_{3}^{-}$is preferred as an electron acceptor over bicarbonate (Conrad, 1989), and some intermediates if $\mathrm{NO}_{3}^{-}$is denitrified $\left(\mathrm{NO}_{2}^{-}, \mathrm{NO}, \mathrm{N}_{2} \mathrm{O}\right)$ can be toxic for methanogenic microorganisms (Klüber and Conrad, 1998).

Methanotrophic microorganisms also need a N source and thus could be N limited (Bender and Conrad, 1995; Bodelier et al., 2000). However, Bodelier and Laanbroek (2004) showed through a literature review that many indications for $\mathrm{N}$ limitation of soil $\mathrm{CH}_{4}$ consumption have been ignored in earlier studies. Apart from the effects $\mathrm{N}$ limitation has on the growth and activity of $\mathrm{CH}_{4}$-oxidizing bacteria, they also proposed that switching from fixation of molecular $\mathrm{N}$ to assimilation of mineral $\mathrm{N}$ can cause almost instantaneous changes in $\mathrm{CH}_{4}$-oxidizing activity.

To date, only one N-manipulation study has been published on $\mathrm{N}$ effects on soil $\mathrm{CH}_{4}$ fluxes from (sub)tropical forests, and this was conducted in China (Zhang et al., 2008; Zhang et al., 2011). In this study, $\mathrm{CH}_{4}$ uptake decreased with increasing $\mathrm{N}$ application rate, whereas in the disturbed and rehabilitated forest no $\mathrm{N}$-addition effect was observed. The authors concluded that the response of soil $\mathrm{CH}_{4}$ uptake to $\mathrm{N}$ addition in tropical forests varied depending on the soil $\mathrm{N}$ status; the lack of effect from the disturbed and rehabilitated forest was explained by intense competition for $\mathrm{N}$ by the vegetation (Zhang et al., 2008).

Here we report the impact of chronic $\mathrm{N}$ additions on soil $\mathrm{CH}_{4}$ fluxes from two species-rich, old-growth forests in Panama: a lowland, moist forest on clayey Cambisol and 
Nitisol soils, and a montane, wet forest on a sandy loam Andosol soil covered with an organic layer. We hypothesized that (1) in the lowland forest, with large soil $\mathrm{N}$-cycling rates (Corre et al., 2010) and tree stem diameter growth $(\geq 10 \mathrm{~cm}$ diameter trees), as well as fine litterfall that is not $\mathrm{N} \mathrm{lim-}$ ited (Wright et al., 2011), long-term $\mathrm{N}$ addition will inhibit $\mathrm{CH}_{4}$ uptake; (2) in the montane forest, with comparatively small soil N-cycling rates (Corre et al., 2010) and tree stem diameter growth (10-50 cm diameter trees), as well as fine litterfall that is $\mathrm{N}$ limited (Adamek et al., 2009), long-term $\mathrm{N}$ addition will stimulate $\mathrm{CH}_{4}$ uptake. We tested these hypotheses by comparing soil $\mathrm{CH}_{4}$ fluxes over a period of four years (2006-2009) in the lowland forest between control and $\mathrm{N}$-addition plots during 9 to $12 \mathrm{yr}$ of $\mathrm{N}$ additions and in the montane forest between control and $\mathrm{N}$-addition plots during 1 to $4 \mathrm{yr}$ of $\mathrm{N}$ additions. Our objectives were to (1) assess changes in soil $\mathrm{CH}_{4}$ fluxes as a result of long-term $\mathrm{N}$ addition, and (2) relate these changes to soil-extractable $\mathrm{NO}_{3}^{-}$, $\mathrm{NH}_{4}^{+}$and soil water-filled pore space, which are factors that potentially control soil $\mathrm{CH}_{4}$ fluxes. This is the first study to report how $\mathrm{CH}_{4}$ fluxes change under chronic $\mathrm{N}$ addition in diverse, old-growth Neotropical forests.

\section{Materials and methods}

\subsection{Approach}

We applied $\mathrm{N}$ fertilizer to create $\mathrm{N}$-enriched conditions, which ultimately will simulate future increased atmospheric $\mathrm{N}$ deposition. $\mathrm{N}$ deposition normally enters the ecosystem at the canopy level at low $\mathrm{N}$ concentrations with each rain shower whereas we applied $\mathrm{N}$ fertilizer to the soil at high $\mathrm{N}$ concentration in four doses per year (see below). One of the artefacts of $\mathrm{N}$ fertilization is the occurrence of pronounced peaks of soil mineral $\mathrm{N}$ concentrations, which can affect short-term $\mathrm{CH}_{4}$ fluxes within the first weeks following $\mathrm{N}$ application (Veldkamp et al., 2001). We therefore did a separate statistical analysis for $\mathrm{CH}_{4}$ fluxes that include all measurements conducted from 1 day to 3 months after an $\mathrm{N}$ application and for $\mathrm{CH}_{4}$ fluxes that were measured $\geq 6$ weeks after the last $\mathrm{N}$ application (hereafter referred as long-term $\mathrm{CH}_{4}$ fluxes). The long-term $\mathrm{CH}_{4}$ fluxes are unlikely to be affected by the artificially high mineral $\mathrm{N}$ concentrations directly following $\mathrm{N}$ application. Furthermore, the type of $\mathrm{N}$ fertilizer (in our case urea) will be less important for the long-term $\mathrm{CH}_{4}$ fluxes because within six weeks following urea application in our study sites, urea- $\mathrm{N}$ was hydrolyzed and processed in the internal soil $\mathrm{N}$ cycle (Koehler et al., 2009).

\subsection{Site description and experimental design}

The lowland forest (25 to $61 \mathrm{~m}$ elevation) consists of an old-growth ( $>200 \mathrm{yr}$ ), semi-deciduous forest and is located on the Gigante Peninsula $\left(9^{\circ} 06^{\prime} \mathrm{N}, 79^{\circ} 50^{\prime} \mathrm{W}\right)$, which is part of the Barro Colorado Nature Monument, Republic of Panama. On the nearby Barro Colorado Island, annual rainfall averages $2715 \pm 139 \mathrm{~mm}$ (1999-2010) with a dry season from January to April. Ambient $\mathrm{N}$ deposition from rainfall was $9 \mathrm{~kg} \mathrm{~N} \mathrm{ha}^{-1} \mathrm{yr}^{-1}$, measured bi-weekly in 20062007 at the shore of Gigante Peninsula near the study site (Corre et al., 2010). The mean annual air temperature is $27.2 \pm 0.1^{\circ} \mathrm{C}$. Stem diameter growth of trees with $\geq 10 \mathrm{~cm}$ diameter at breast height (dbh), fine litter production, and fine-root biomass within $0-10 \mathrm{~cm}$ depth were not affected by $11 \mathrm{yr}$ of $\mathrm{N}$ addition (Wright et al., 2011). The soils are Endogleyic Cambisol in the lower parts of the landscape and Acric Nitisol in the upper parts of the landscape, both with heavy clay texture. Bulk density was $0.62 \mathrm{~g} \mathrm{~cm}^{-3}$ in the top $5 \mathrm{~cm}$ depth of mineral soil (Koehler et al., 2009). After 8 yr of N addition, we measured significant decreases in soil $\mathrm{pH}$ (control $=5.1 \pm 0.1, \mathrm{~N}$ addition $=4.8 \pm 0.1)$ and base saturation (control $=67 \pm 8 \%, \mathrm{~N}$ addition $=41 \pm 7 \%$ ), while exchangeable aluminium (Al) increased (control $=213 \pm 39 \mathrm{~g} \mathrm{Al} \mathrm{m}^{-2}$, $8 \mathrm{yr} \mathrm{N}$ addition $=297 \pm 44 \mathrm{~g} \mathrm{Al} \mathrm{m}^{-2}$ ) in the top $50 \mathrm{~cm}$ of mineral soil.

The montane forest (1200-1300 m elevation) consists of an old-growth lower montane forest and is located in the Fortuna Forest Reserve in the Cordillera Central $\left(8^{\circ} 45^{\prime} \mathrm{N}\right.$, $82^{\circ} 15^{\prime} \mathrm{W}$ ), Chiriquí Province, Republic of Panama. Mean annual rainfall is $5461 \pm 250 \mathrm{~mm}$ (1997-2010) with no dry season. Ambient $\mathrm{N}$ deposition from rainfall was $5 \mathrm{~kg} \mathrm{Nha}^{-1} \mathrm{yr}^{-1}$, measured biweekly in 2006-2007 at a forest clearing near the study site (Corre et al., 2010). The annual mean air temperature is $20.3 \pm 0.2{ }^{\circ} \mathrm{C}$. Stem diameter growth of trees with $10-50 \mathrm{~cm}$ dbh and fine litter production increased during the first two years of $\mathrm{N}$ addition compared with the control plots (Adamek et al., 2009), whereas fine-root biomass and production (from organic layer down to $20 \mathrm{~cm}$ depth of the mineral soil) were not affected by $\mathrm{N}$ addition (Adamek et al., 2011). The soil is Aluandic Andosol with sandy loam texture and has an organic layer thickness of $10 \pm 1 \mathrm{~cm}$. Bulk density of the organic layer was $0.07 \mathrm{~g} \mathrm{~cm}^{-3}$ and the underlying mineral soil had a bulk density of $0.47 \mathrm{~g} \mathrm{~cm}^{-3}$ in first $5 \mathrm{~cm}$ depth (Koehler et al., 2009). After $3 \mathrm{yr}$ of $\mathrm{N}$ addition no significant changes in $\mathrm{pH}$ (control $=4.7 \pm 0.1, \quad \mathrm{~N}$ addition $=4.6 \pm 0.2$ ), base saturation $\quad($ control $=8 \pm 3 \%, \quad \mathrm{~N}$ addition $=11 \pm 4 \%)$, and exchangeable $\mathrm{Al}$ (control $=252 \pm 16 \mathrm{~g} \mathrm{Al} \mathrm{m}^{-2}$, $\mathrm{N}$ addition $=280 \pm 24 \mathrm{~g} \mathrm{Al} \mathrm{m}^{-2}$ ) were observed in the top $50 \mathrm{~cm}$ of mineral soil.

The $\mathrm{N}$-addition experiment in the lowland forest was part of an on-going nutrient manipulation study established in 1998 (Wright et al., 2011). The experiment includes Naddition and control plots, among other treatments, laid out in four replicates across a 26.6 ha area in a stratified random design. In the montane forest, the experiment was set up in 2006 in a paired-plot design with four replicates of control and $\mathrm{N}$-addition plots (Corre et al., 2010). At both sites, the size of the plots was $40 \mathrm{~m} \times 40 \mathrm{~m}$, separated by at least $40 \mathrm{~m}$ of buffer zone where no manipulation was 
done. The $\mathrm{N}$-addition plots received $125 \mathrm{~kg}$ urea-N ha ${ }^{-1} \mathrm{yr}^{-1}$ split in four applications (i.e. during the rainy season (MayDecember) for the lowland forest, and every quarter of the year for the montane forest). Measurements were conducted in the central $20 \mathrm{~m} \times 20 \mathrm{~m}$ area of the plot to prevent possible edge effects (e.g. roots from trees outside the plots growing into the $\mathrm{N}$-fertilized plots).

\section{$2.3 \quad \mathrm{CH}_{4}$ flux measurements}

Soil $\mathrm{CH}_{4}$ fluxes were measured using vented static chambers. Four permanent chamber bases (area $0.04 \mathrm{~m}^{2}$, height $0.25 \mathrm{~m}$, total volume with cover $11 \mathrm{~L}$ ) were installed on each plot in a stratified random design along two perpendicular $20 \mathrm{~m}$ long transects that crossed in the plot's centre. During the first two years (2006-2007), sampling frequency was from once a month to four times a month when we intensively measured following an $\mathrm{N}$ application. During the third and fourth year (2008-2009), sampling was conducted at least once a month. Four gas samples $(100 \mathrm{~mL}$ each) were removed at 2, 12, 22 and $32 \mathrm{~min}$ after chamber closure and stored in pre-evacuated glass containers with a teflon-coated stopcock. Gas samples were analyzed in the field station in Panama using a gas chromatograph (Shimadzu GC-14B, Columbia, MD, USA) equipped with a flame ionization detector and an autosampler (Loftfield et al., 1997). $\mathrm{CH}_{4}$ concentrations were determined by comparison of integrated peak areas of samples with those of three to four standard gases (depending on concentrations: 250, 1499, 1996, 9900 and $20010 \mathrm{ppb} \mathrm{CH}_{4}$; Deuste Steininger $\mathrm{GmbH}$, Mühlhausen, Germany). Gas fluxes were calculated from the concentration change in the chamber versus time and were adjusted for air temperature and atmospheric pressure measured at the time of sampling. To account for the decreasing diffusion gradient over time caused by the chamber feedback, we fitted both a linear and a quadratic regression model if $\mathrm{CH}_{4}$ concentrations increased or decreased asymptotically (Wagner et al., 1997). We chose the statistically more adequate model based on the Akaike information criterion. The quadratic model was used in $14 \%$ of the flux calculations in the montane forest and in $20 \%$ of the gas flux calculations in the lowland forest. If $\mathrm{CH}_{4}$ concentrations leveled out over time and the quadratic model was statistically inferior, we excluded the last data point and calculated the flux based on a linear model. These data screening and calculation procedures ensure that we minimized underestimations which may occur if a linear model was uncritically applied to static chamber flux data (Livingston et al., 2006). Positive fluxes indicate $\mathrm{CH}_{4}$ emission from the soil; negative fluxes indicate $\mathrm{CH}_{4}$ uptake by the soil. Zero fluxes were included. The annual $\mathrm{CH}_{4}$ fluxes were approximated by applying the trapezoid rule (linear interpolation of time intervals between measured flux rates), assuming constant flux rates per day.

\subsection{Soil mineral $\mathrm{N}$ and moisture}

From earlier experience in tropical forests, we learned that short storage of disturbed soil samples can considerably alter mineral $\mathrm{N}$ concentrations (Arnold et al., 2008). We therefore conducted mineral $\mathrm{N}$ extractions in the field. Parallel to gas sampling, four samples of mineral soil ( $0-0.05 \mathrm{~m}$ depth) were collected within the central $10 \mathrm{~m} \times 10 \mathrm{~m}$ of each plot. For the montane site, we sampled the organic layer and 0$5 \mathrm{~cm}$ depth mineral soil separately. While in the field, samples were pooled for each plot, leaves and roots were manually removed, and a subsample (50-60 g fresh weight) was added to a prepared extraction bottle containing $150 \mathrm{~mL}$ of $0.5 \mathrm{~mol} \mathrm{~L}^{-1} \mathrm{~K}_{2} \mathrm{SO}_{4}$. Shaking $(1 \mathrm{~h})$ and filtering continued upon arrival at the field station, which was at most $6 \mathrm{~h}$ after field extraction. Soil extracts were stored in a freezer and kept frozen during air transport to the University of Göttingen (Germany), where $\mathrm{NH}_{4}^{+}$and $\mathrm{NO}_{3}^{-}$contents were analyzed using continuous flow injection colorimetry (Cenco/Skalar Instruments, Breda, Netherlands). $\mathrm{NH}_{4}^{+}$was determined using the Berthelot reaction method (Skalar Method 155-000) and $\mathrm{NO}_{3}^{-}$was measured using the copper-cadmium reduction method $\left(\mathrm{NH}_{4} \mathrm{Cl}\right.$ buffer but without ethylenediamine tetraacetic acid; Skalar Method 461-000). The rest of the field-moist sample was stored in plastic bags for gravimetric moisture determination, conducted in the field station on the same sampling day. We dried $40-100 \mathrm{~g}$ of fresh-weight soil for $24 \mathrm{~h}$ at $105^{\circ} \mathrm{C}$. We expressed moisture content as WFPS using measured bulk density and particle densities of $2.65 \mathrm{~g} \mathrm{~cm}^{-3}$ for mineral soil (Linn and Doran, 1984) and $1.4 \mathrm{~g} \mathrm{~cm}^{-3}$ for organic layer (Breuer et al., 2002).

\subsection{Statistical analyses}

For $\mathrm{CH}_{4}$ fluxes, statistical analysis was conducted on the plot means (average of 4 chambers) of each sampling day. Linear mixed effects models were used to test for the fixed effects of site (lowland vs. montane control plots) or treatment (control vs. $\mathrm{N}$ addition for each site) on the repeated measurements of soil $\mathrm{CH}_{4}$ fluxes and soil factors (WFPS, soil temperature, $\mathrm{NH}_{4}^{+}$and $\mathrm{NO}_{3}^{-}$concentrations). The spatial replication and time (sampling days) were included as random effect. A function which allows different variances of the response variable per level of the fixed effect and/or a first-order temporal autoregressive process was included if this improved the relative goodness of the model fit based on likelihood ratio tests. The significance of the fixed effect was evaluated using analysis of variance (Crawley, 2009). If residual plots revealed non-normal distribution or non-homogenous variance, square root or logarithmic transformation was used for right-skewed data and quadratic transformation for leftskewed data, and the analysis was repeated. Effects were considered significant if $P$ value $\leq 0.05$. Pearson correlation tests were conducted on treatment means (average of 4 plots) of each sampling day to investigate the linear influences 
of WFPS, soil temperature, $\mathrm{NH}_{4}^{+}$and $\mathrm{NO}_{3}^{-}$concentrations on soil $\mathrm{CH}_{4}$ fluxes. A few $\mathrm{CH}_{4}$ fluxes from the $\mathrm{N}$-addition plots of the montane forest were exceptionally high (21 out of 196 plot means with emissions $>60 \mu \mathrm{g} \mathrm{CH}_{4}-\mathrm{C} \mathrm{m}^{-2} \mathrm{~h}^{-1}$ ), and correlation analyses were conducted both including (using logarithmic transformation) and excluding these high emissions. We also used Pearson correlation to test the influences of annual rainfall, soil clay and sand contents, organic layer thickness, and annual $\mathrm{N}$ deposition on annual soil $\mathrm{CH}_{4}-$ $\mathrm{C}$ fluxes of tropical forests published so far. Mean values in the text are given with \pm 1 standard error. Analyses were conducted using R 2.15.2 (R Development Core Team, 2011).

\section{Results}

\subsection{Soil water content, temperature and mineral $\mathbf{N}$}

In the lowland forest, the pronounced dry season from January to April caused a strong seasonality in WFPS, which ranged from approximately 55-70\% during rainy season to 35-45\% during dry season (Fig. 1a). Mean annual soil temperature was $25.5^{\circ} \mathrm{C}$ and the seasonal variation was $2.5^{\circ} \mathrm{C}$ (Fig. 1c). Neither WFPS nor soil temperature differed between the control and $\mathrm{N}$-addition plots $(P=0.37$ to 0.95$)$. In the montane forest, where the dry season is absent, the WFPS in the mineral soil was high (70-80\%) throughout the year. The organic layer with its low bulk density had a much lower WFPS (20-35\%; Fig. 1b). Mean annual soil temperature was $18.1^{\circ} \mathrm{C}$ and the seasonal variation was $3.8^{\circ} \mathrm{C}$ (Fig. 1d). Also, WFPS and soil temperature were similar between the control and $\mathrm{N}$-addition plots ( $P=0.31$ to 0.47 ).

In the lowland forest, $\mathrm{NH}_{4}^{+}$concentrations did not differ between the control and $\mathrm{N}$-addition plots $(P=0.82)$ (Fig. 2a), but $\mathrm{NO}_{3}^{-}$concentrations increased with $\mathrm{N}$ addition $(P<0.01)$ (Fig. 2b). In the montane forest, mineral $\mathrm{N}$ was dominated by $\mathrm{NH}_{4}^{+}$in both organic layer and mineral soil. $\mathrm{N}$ addition increased $\mathrm{NH}_{4}^{+}$concentrations in the mineral soil $(P<0.01)$ but did not show an effect on $\mathrm{NH}_{4}^{+}$ concentrations in the organic layer $(P=0.31)$ (Fig. $2 \mathrm{c}$ and e). $\mathrm{NO}_{3}^{-}$concentrations increased in both mineral soil $(P=$ $0.01)$ and organic layer $(P=0.03)$ with very large increases in the fourth year of $\mathrm{N}$ addition (Fig. $2 \mathrm{~d}$ and $\mathrm{f}$ ).

\section{2 $\mathrm{CH}_{4}$ fluxes from control forest soils}

$\mathrm{CH}_{4}$ fluxes from the lowland forest control plots $\left(-21.47 \pm 1.57 \mu \mathrm{g} \mathrm{CH}_{4}-\mathrm{C} \mathrm{m}^{-2} \mathrm{~h}^{-1}\right)$ did not differ $(P=0.82)$ from the fluxes of the montane forest control plots $\left(-3.99 \pm 3.40 \mu \mathrm{g} \mathrm{CH}_{4}-\mathrm{C} \mathrm{m}^{-2} \mathrm{~h}^{-1}\right.$; Fig. 3, Table 1). This seemingly larger $\mathrm{CH}_{4}$ uptake rates in this moist $\left(2.7 \mathrm{~m} \mathrm{yr}^{-1}\right.$ rainfall) lowland forest soil than the wet $\left(5.5 \mathrm{~m} \mathrm{yr}^{-1}\right.$ rainfall) montane forest soil was not statistically significant because of the large spatial and temporal variations (Fig. 3). Before elaborating on how soil factors influence $\mathrm{CH}_{4}$ fluxes, we want to point out the implications of correlations: a positive correlation between $\mathrm{CH}_{4}$ fluxes and a soil variable indicates a decrease in $\mathrm{CH}_{4}$ uptake rates with an increase in the soil parameter values, whereas a negative correlation indicates an increase in $\mathrm{CH}_{4}$ uptake rates with an increase in the soil parameter values. In the lowland forest, $\mathrm{CH}_{4}$ fluxes were positively correlated with WFPS (Table 2). In the montane forest, $\mathrm{CH}_{4}$ fluxes were negatively correlated with $\mathrm{NH}_{4}^{+}$concentrations and positively correlated with $\mathrm{NO}_{3}^{-}$concentrations of the organic layer and mineral soil (Table 2). These opposing correlations of $\mathrm{CH}_{4}$ fluxes with $\mathrm{NH}_{4}^{+}$and $\mathrm{NO}_{3}^{-}$were because the temporal patterns of $\mathrm{NH}_{4}^{+}$and $\mathrm{NO}_{3}^{-}$showed the opposite trend (Fig. 2c-f). The correlation between $\mathrm{CH}_{4}$ fluxes and total soil mineral $\mathrm{N}\left(\mathrm{NH}_{4}^{+}+\mathrm{NO}_{3}^{-}\right)$concentrations (organic layer $R=-0.51, P=0.01, n=28$; mineral soil $R=-0.56$, $P=0.00, n=27$ ) followed that of $\mathrm{NH}_{4}^{+}$, because $\mathrm{NH}_{4}^{+}$ comprised the largest part of mineral $\mathrm{N}$.

\subsection{Effects of $\mathrm{N}$ addition on soil $\mathrm{CH}_{4}$ fluxes}

In the lowland forest, neither all $\mathrm{CH}_{4}$ fluxes $\left(-24.22 \pm 1.64 \mu \mathrm{g} \mathrm{C} \mathrm{m}^{-2} \mathrm{~h}^{-1}\right)$ nor the long-term $\mathrm{CH}_{4}$ fluxes $\left(-26.14 \pm 2.00 \mu \mathrm{g} \mathrm{C} \mathrm{m}^{-2} \mathrm{~h}^{-1}\right)$ from the $\mathrm{N}$-addition plots differed ( $P=0.55$ to 0.57 ) from the $\mathrm{CH}_{4}$ fluxes of the control plots (Fig. 3a and c; Table 1). The reason was the occasional $\mathrm{CH}_{4}$ emissions from three of the four replicate plots of the control and $\mathrm{N}$-addition treatment regardless of seasons (46 emission fluxes out of 373 plot-mean fluxes or $12 \%$ of the observations, ranging from 0.4 to $210 \mu \mathrm{g} \mathrm{C} \mathrm{m}^{-2} \mathrm{~h}^{-1}$ ), resulting in the large spatial and temporal variations (i.e. large SE bars; Fig. 3a and c). For all $\mathrm{CH}_{4}$ fluxes, we detected a positive correlation with WFPS and negative correlations with soil temperatures and $\mathrm{NO}_{3}^{-}$concentrations (Table 2). The same soil factors showed similar trends of correlations with the long-term $\mathrm{CH}_{4}$ fluxes (Table 2).

In the montane forest, despite the large mean $\mathrm{CH}_{4}$ emissions from the $\mathrm{N}$-addition plots (for all $\mathrm{CH}_{4}$ fluxes $50.94 \pm 19.62 \mu \mathrm{g} \mathrm{m}^{-2} \mathrm{~h}^{-1}$; for long-term $\mathrm{CH}_{4}$ fluxes $\left.62.13 \pm 31.26 \mu \mathrm{g} \mathrm{C} \mathrm{m}^{-2} \mathrm{~h}^{-1}\right)$, neither all $\mathrm{CH}_{4}$ fluxes nor the long-term $\mathrm{CH}_{4}$ fluxes differed ( $P=0.32$ to 0.71 ) from those of the control plots (Fig. 3b and d; Table 1). The reason was that frequent $\mathrm{CH}_{4}$ emissions were observed from all eight plots (83 emission fluxes out of 351 plot-mean fluxes or $24 \%$ of the observations, ranging from 0.2 to $2575 \mu \mathrm{g} \mathrm{C} \mathrm{m}^{-2} \mathrm{~h}^{-1}$ ). These $\mathrm{CH}_{4}$ emissions were dominated by one pair of control and $\mathrm{N}$-addition plots (49 emission fluxes out of 351 plotmean fluxes), causing the large spatial and temporal variations (i.e. large SE bars; Fig. $3 \mathrm{~b}$ and d). If we exclude this one pair of control and $\mathrm{N}$-addition plots from the statistical analysis, there remained no difference between the $\mathrm{N}$-addition and control plots $(P=0.28$ to 0.82$)$, but the mean $\mathrm{CH}_{4}$ fluxes showed net uptake instead of net emission (Table 1). Also, a few $\mathrm{CH}_{4}$ emissions from $\mathrm{N}$-addition plots were exceptionally high (21 out of 196 plot means with emissions 
Table 1. Annual soil $\mathrm{CH}_{4}-\mathrm{C}$ fluxes $\left(\mathrm{kg} \mathrm{Cha}^{-1} \mathrm{yr}^{-1}\right.$, mean $\left.\pm \mathrm{SE}, n=4\right)$ from the control and $\mathrm{N}$-addition plots, separated into all and longterm fluxes, with the latter including only the fluxes measured at least six weeks after a $\mathrm{N}$ application. For the montane forest, values in parentheses are estimates that excluded one pair of plots (control and $\mathrm{N}$ addition) which dominated $\mathrm{CH}_{4}$ emissions (49 emission fluxes out of 351 plot-mean fluxes).

\begin{tabular}{llllll}
\hline Site & Treatment & 2006 & 2007 & 2008 & 2009 \\
\hline Montane & Control & $-1.69 \pm 0.36$ & $-1.18 \pm 0.41$ & $-0.53 \pm 0.50$ & $1.91 \pm 2.49$ \\
& & $(-1.83 \pm 0.48)$ & $(-1.15 \pm 0.58)$ & $(-0.93 \pm 0.42)$ & $(-0.56 \pm 0.57)$ \\
& 1-4 yr N addition, all fluxes & $-1.86 \pm 0.57^{*}$ & $7.64 \pm 9.40$ & $4.42 \pm 5.86$ & $8.99 \pm 10.41$ \\
& & $(-2.37 \pm 0.35)$ & $(-1.75 \pm 0.30)$ & $(-1.42 \pm 0.59)$ & $(-1.42 \pm 0.38)$ \\
& & $-2.19 \pm 0.76^{*}$ & $8.34 \pm 9.97$ & $5.36 \pm 6.82$ & $8.56 \pm 9.89$ \\
& & $(-2.91 \pm 0.37)$ & $(-1.63 \pm 0.30)$ & $(-1.44 \pm 0.63)$ & $(-1.33 \pm 0.43)$ \\
\hline \multirow{2}{*}{ Lowland N addition, long-term fluxes } & Control & $-1.93 \pm 0.24$ & $-1.82 \pm 0.51$ & $-2.38 \pm 0.54$ & $-1.60 \pm 0.45$ \\
& $9-12$ yr N addition, all fluxes & $-2.33 \pm 0.85$ & $-2.22 \pm 0.60$ & $-1.94 \pm 0.98$ & $-2.20 \pm 0.50$ \\
& $9-12$ yr N addition, long-term fluxes & $-2.09 \pm 0.92$ & $-2.42 \pm 0.68$ & $-2.15 \pm 0.51$ & $-2.16 \pm 0.51$ \\
\hline
\end{tabular}

* The two pre-treatment measurements from January and February 2006 were not included in the calculation.
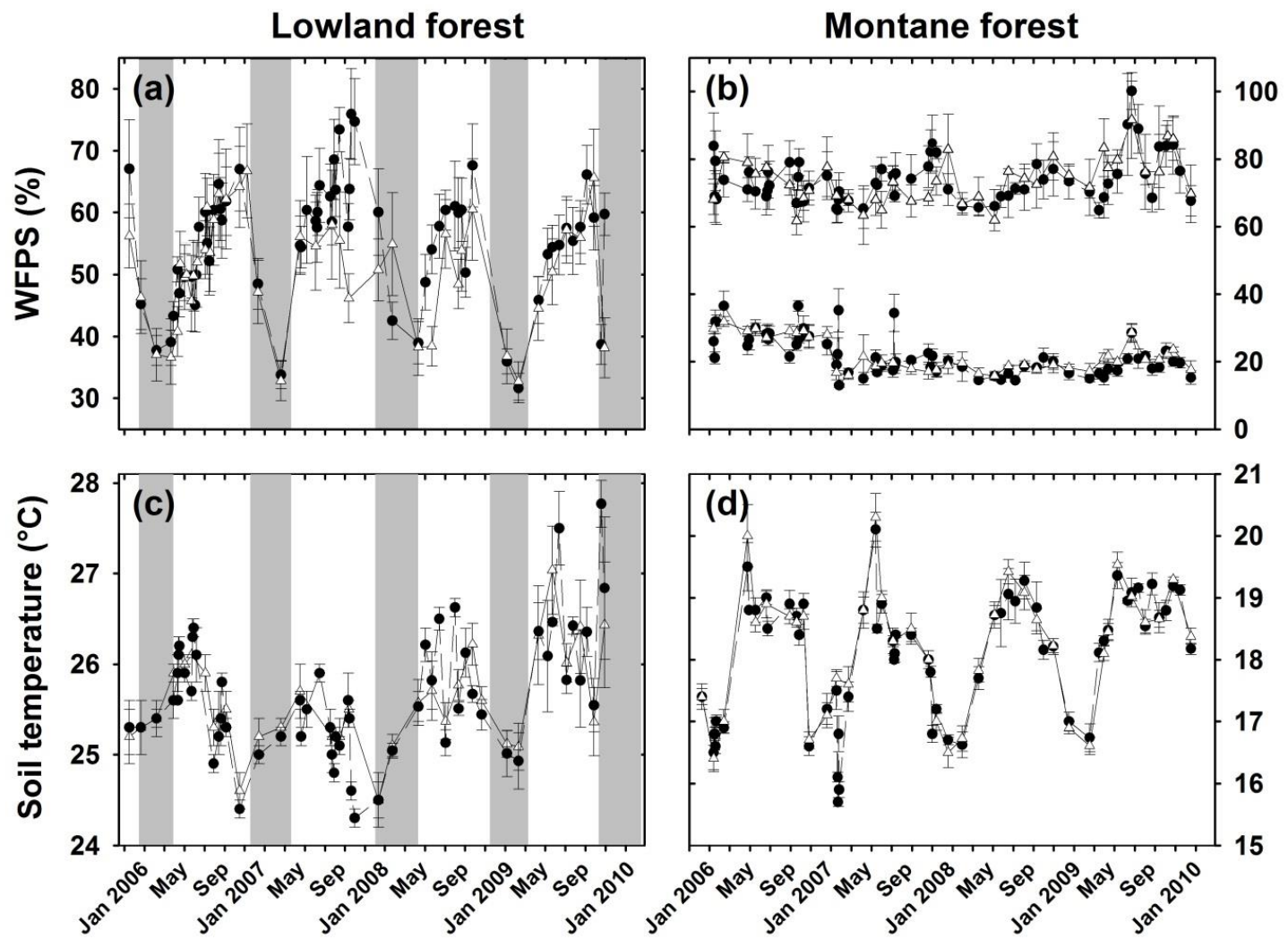

Fig. 1. Mean $( \pm \mathrm{SE}, n=4)$ soil water-filled pore space (WFPS) and temperature at $0-0.05 \mathrm{~m}$ mineral soil in the control $(\triangle)$ and $\mathrm{N}$-addition (•) plots of the lowland forest (a and c) with 9-12 yr of treatment and of the montane forest (b and d) with 1-4 yr of treatment. For WFPS in the montane forest, the upper and lower values are for the $0-0.05 \mathrm{~m}$ mineral soil and organic layer, respectively. Grey shadings in (a) and (c) mark the dry seasons. The first two years were previously reported by Koehler et al. (2009).

$>60 \mu \mathrm{g} \mathrm{CH}_{4}-\mathrm{C} \mathrm{m}^{-2} \mathrm{~h}^{-1}$ ). Thus, we looked critically at how these few high $\mathrm{CH}_{4}$ emissions influence the relationships between $\mathrm{CH}_{4}$ fluxes and soil factors. We first analyzed the correlations between $\mathrm{CH}_{4}$ fluxes and soil factors that include all emission fluxes and that exclude the exceptionally high $\mathrm{CH}_{4}$ emissions of $>60 \mu \mathrm{g} \mathrm{CH}_{4}-\mathrm{Cm}^{-2} \mathrm{~h}^{-1}$. Considering all $\mathrm{CH}_{4}$ fluxes, we observed a positive correlation with WFPS of the mineral soil and a negative correlation with $\mathrm{NH}_{4}^{+}$concentrations of the organic layer when the large emissions were included. When the large emissions were excluded, $\mathrm{CH}_{4}$ fluxes 

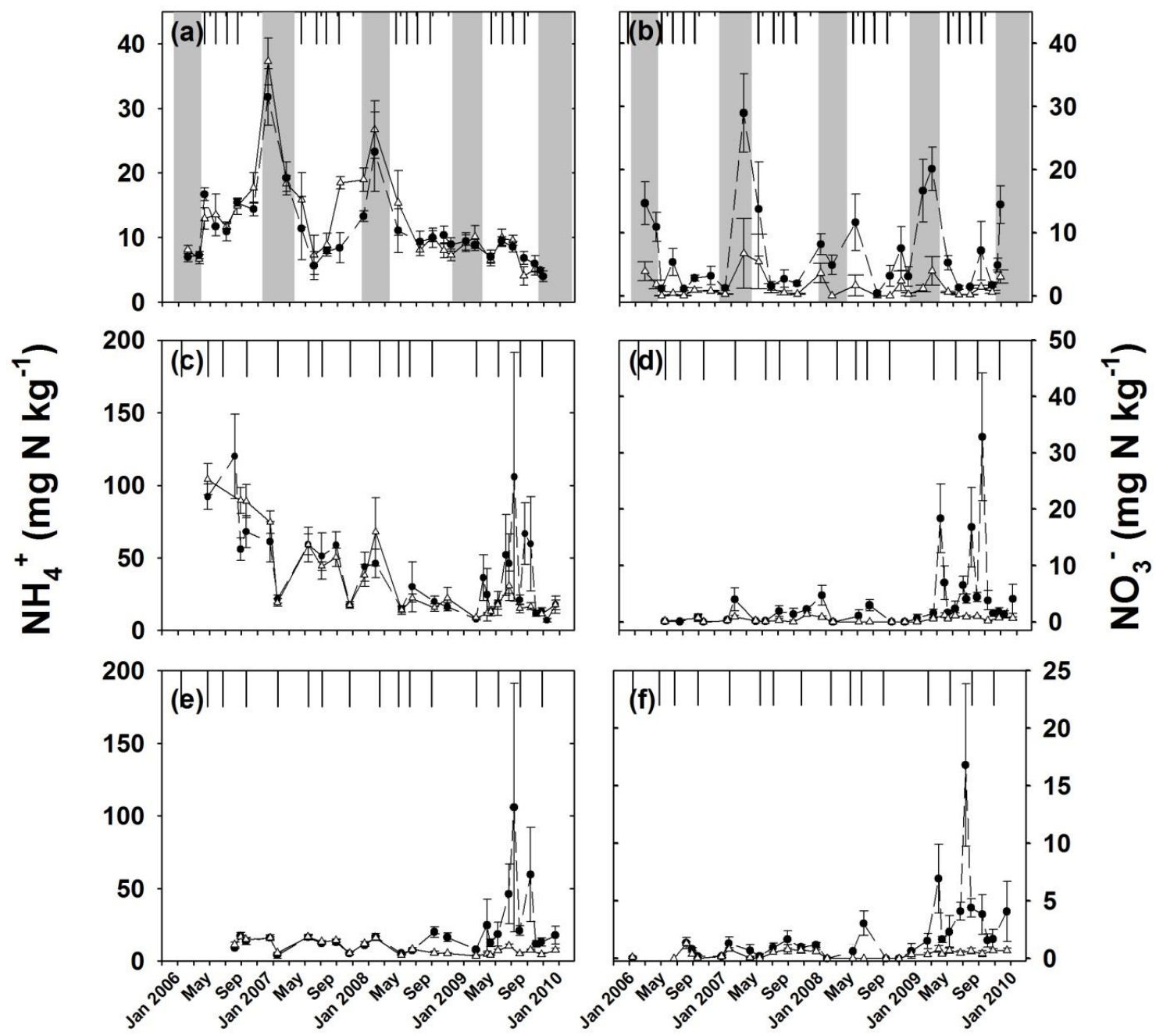

Fig. 2. Mean $( \pm \mathrm{SE}, n=4)$ soil-extractable ammonium $\left(\mathrm{NH}_{4}^{+}\right.$, left panels) and nitrate $\left(\mathrm{NO}_{3}^{-}\right.$, right panels $)$at $0-0.05 \mathrm{~m}$ mineral soil in the control $(\triangle)$ and $\mathrm{N}$-addition $(\bullet)$ plots of the lowland forest $(\mathbf{a}$ and $\mathbf{b})$ and montane forest ( $\mathbf{c}$ and $\mathbf{d}$ for organic layer, $\mathbf{e}$ and $\mathbf{f}$ for $0-0.05 \mathrm{~m}$ mineral soil). The black vertical lines indicate dates of $\mathrm{N}$ addition during 9-12 yr of treatment in the lowland forest and 1-4 yr of treatment in the montane forest. Grey shadings in (a) and (b) mark the dry seasons. The first two years were previously reported by Koehler et al. (2009).

remained negatively correlated with $\mathrm{NH}_{4}^{+}$concentrations of the organic layer (Table 2). Considering only the long-term $\mathrm{CH}_{4}$ fluxes, we observed also a negative correlation with $\mathrm{NH}_{4}^{+}$concentrations of the organic layer both including and excluding the large emissions (Table 2).

\section{Discussion}

\section{1 $\mathrm{CH}_{4}$ fluxes from control forests in comparison with published values}

The mean annual $\mathrm{CH}_{4}$ uptake rate in the control plots of the lowland forest was within the range of published values from (sub)tropical forests below $800 \mathrm{~m}$ elevation (Table 3). The few published $\mathrm{CH}_{4}$ uptake rates that were lower than our lowland forest soil were mainly from Amazon forest soils with low sand or high clay contents, while those with larger $\mathrm{CH}_{4}$ uptake rates were mostly at sites with low clay content (Steudler et al., 1996; Sousa Neto et al., 2011). Indeed, from studies compiled (Table 3), the only significant correlation between annual $\mathrm{CH}_{4}$ fluxes and site factors for the tropical forests below $800 \mathrm{~m}$ elevation was a positive correlation between annual soil $\mathrm{CH}_{4}$ fluxes and clay contents $(R=0.58$, $P=0.02, n=16$ ). A high content of clay decreases the contribution of coarse pores to the total porosity (Hillel, 1998). As coarse pores are especially important for gas diffusive transport, soil texture may be a good proxy variable for gas diffusion control on $\mathrm{CH}_{4}$ uptake. Consistent with this correlation pattern, earlier studies have shown that $\mathrm{CH}_{4}$ uptake is often limited by gas diffusion in the soil (Keller and Reiners, 1994). Also, the seasonal changes in $\mathrm{CH}_{4}$ uptake of our lowland forest soil (Fig. 3a, c) were best explained by gas 
Table 2. Pearson correlation coefficients between soil $\mathrm{CH}_{4}-\mathrm{C}$ fluxes $\left(\mu \mathrm{g} \mathrm{m}^{-2} \mathrm{~h}^{-1}\right)$ and soil variables, using the mean values of each treatment on each sampling day, measured from 2006 to 2009. For the montane forest $\mathrm{N}$-addition plots, coefficients in parentheses are from analyses that include the few events of large $\mathrm{CH}_{4}$ emissions (please see Sect. 2.5).

\begin{tabular}{|c|c|c|c|c|c|}
\hline Site and treatment & $n \geq$ & $\begin{array}{l}\text { Water-filled } \\
\text { pore space } \\
(\%)\end{array}$ & $\begin{array}{l}\mathrm{NH}_{4}^{+} \\
\left(\mathrm{mg} \mathrm{Nkg}^{-1}\right)\end{array}$ & $\begin{array}{l}\mathrm{NO}_{3}^{-} \\
\left(\mathrm{mgNkg}^{-1}\right)\end{array}$ & $\begin{array}{l}\text { Soil } \\
\text { temperature } \\
\left({ }^{\circ} \mathrm{C}\right)\end{array}$ \\
\hline Montane & \multicolumn{5}{|c|}{ Organic layer } \\
\hline Control & 28 & -0.31 & $-0.58^{\mathrm{b}, \mathrm{c}}$ & $0.62^{\mathrm{b}, \mathrm{c}}$ & - \\
\hline $1-4 \mathrm{yr} \mathrm{N}$ addition, including all fluxes & 27 & $\begin{array}{l}-0.05 \\
(-0.18)\end{array}$ & $\begin{array}{l}-0.43^{\mathrm{a}, \mathrm{c}} \\
\left(-0.38^{\mathrm{a}, \mathrm{c}}\right)\end{array}$ & $\begin{array}{l}-0.12^{\mathrm{c}} \\
\left(0.34^{\mathrm{c}}\right)\end{array}$ & - \\
\hline $\begin{array}{l}1-4 \mathrm{yr} \mathrm{N} \text { addition, long-term fluxes } \\
\text { (i.e. measured } \geq 6 \text { weeks after } \mathrm{N} \text { addition) }\end{array}$ & 24 & $\begin{array}{l}-0.13 \\
(0.06)\end{array}$ & $\begin{array}{l}-0.48^{\mathrm{a}, \mathrm{c}} \\
\left(-0.44^{\mathrm{a}, \mathrm{c}}\right)\end{array}$ & $\begin{array}{l}0.11^{\mathrm{c}} \\
(0.29)^{\mathrm{c}}\end{array}$ & - \\
\hline Montane & \multicolumn{5}{|c|}{ 0-0.05 m mineral soil } \\
\hline Control & 27 & 0.26 & $-0.56^{\mathrm{b}}$ & $0.54^{\mathrm{b}, \mathrm{c}}$ & -0.17 \\
\hline $1-4$ yr $\mathrm{N}$ addition, including all fluxes & 26 & $\begin{array}{l}0.14 \\
\left(0.37^{b}\right)\end{array}$ & $\begin{array}{l}-0.25 \\
(-0.31)\end{array}$ & $\begin{array}{l}-0.35^{\mathrm{c}} \\
\left(0.16^{\mathrm{c}}\right)\end{array}$ & $\begin{array}{l}-0.16 \\
(0.09)\end{array}$ \\
\hline 1-4 yr $\mathrm{N}$ addition, long-term fluxes & 23 & $\begin{array}{l}-0.09 \\
(0.30)\end{array}$ & $\begin{array}{l}-0.33 \\
(-0.36)\end{array}$ & $\begin{array}{l}-0.01^{\mathrm{c}} \\
(0.08)^{\mathrm{c}}\end{array}$ & $\begin{array}{l}0.02 \\
(0.14)\end{array}$ \\
\hline Lowland & \multicolumn{5}{|c|}{ 0-0.05 m mineral soil } \\
\hline Control & 32 & $0.57^{\mathrm{b}}$ & $-0.03^{c}$ & $-0.14^{\mathrm{c}}$ & -0.02 \\
\hline $9-12$ yr $\mathrm{N}$ addition, including all fluxes & 33 & $0.49^{b}$ & $0.16^{\mathrm{c}}$ & $-0.40^{\mathrm{a}, \mathrm{c}}$ & $-0.34^{\mathrm{a}}$ \\
\hline $9-12 \mathrm{yr} \mathrm{N}$ addition, long-term fluxes & 28 & $0.54^{\mathrm{b}}$ & $0.27^{\mathrm{c}}$ & $-0.37^{\mathrm{a}, \mathrm{c}}$ & $-0.39^{\mathrm{a}}$ \\
\hline
\end{tabular}

a, b: $P \leq 0.05$ and $P \leq 0.01$, respectively.

${ }^{c}$ Data were logarithmically transformed before analysis (please see Sect. 2.5 ).

diffusion, as was illustrated by the correlation of $\mathrm{CH}_{4}$ fluxes with WFPS (Table 2); during the wet season when WFPS was high, $\mathrm{CH}_{4}$ uptake was low because $\mathrm{CH}_{4}$ diffusion from the atmosphere to this site's clayey soils was probably slowed down by the high soil water contents.

The mean annual $\mathrm{CH}_{4}$ uptake rate in the control plots of the montane forest was the lowest published so far for tropical forests above $800 \mathrm{~m}$ elevation (Table 3 ). This was caused by the frequent $\mathrm{CH}_{4}$ emissions from our wet, montane forest soil (Fig. 3b and d). From tropical forests above $800 \mathrm{~m}$ elevation (Table 3), we detected a positive correlation between annual $\mathrm{CH}_{4}$ fluxes and rainfall $(R=0.78, P=0.04, n=7)$, which is in line with the gas diffusion control on soil $\mathrm{CH}_{4}$ uptake as discussed above. Rainfall influences gas diffusion through its effects on soil moisture content. However, in contrast to the forests below $800 \mathrm{~m}$ elevation, we detected a negative correlation with clay contents $(R=-0.68, P=0.04$, $n=9$ ). This can probably be explained by the occurrence of thick organic layers (Table 3 ) at the surface of some of these soils, which may interfere with gas exchange between soil and atmosphere. From an earlier study we conducted in montane forests of Ecuador, we found that, contrary to common belief, the deeper part of such organic layers can contribute to the $\mathrm{CH}_{4}$-oxidation capacity of soils (Wolf et al., 2012). The thickness, bulk density and $\mathrm{CH}_{4}$-oxidation capacity of these organic layers may influence $\mathrm{CH}_{4}$ uptake stronger than the soil texture of the underlying mineral soil. We also detected a positive correlation between annual $\mathrm{CH}_{4}$ fluxes and annual $\mathrm{N}$ deposition rates $(R=0.96, P<0.00, n=6)$ of tropical forests above $800 \mathrm{~m}$ elevation. This may suggest that $\mathrm{CH}_{4}$ uptake is lower at sites with higher $\mathrm{N}$ deposition. However, this correlation is based on six sites that had $\mathrm{N}$ deposition rates of only $\leq 5.0 \mathrm{~kg} \mathrm{Nha}^{-1} \mathrm{yr}^{-1}$. At such low rates of $\mathrm{N}$ deposition, we think that inhibition of $\mathrm{CH}_{4}$ oxidation by $\mathrm{NH}_{4}^{+}$is unlikely. Instead, we think that such correlation is only circumstantial because in these six sites annual $\mathrm{N}$ deposition was positively correlated with annual rainfall ( $R=0.89, P=0.02, n=6$ ), signifying that low $\mathrm{CH}_{4}$ uptake was reported for sites with high rainfall and high $\mathrm{N}$ deposition. Thus, we think it is more likely that soil water content (which controls gas diffusion) as influenced by rainfall was the reason behind the observed correlation between annual $\mathrm{CH}_{4}$ fluxes and annual $\mathrm{N}$ deposition rates.

For the control plots of the montane forest, we interpret the negative correlations of $\mathrm{CH}_{4}$ fluxes with $\mathrm{NH}_{4}^{+}$and total mineral $\mathrm{N}$ concentrations as evidence that $\mathrm{CH}_{4}$ consumption was $\mathrm{N}$ limited. We had similar findings of negative correlation between $\mathrm{CH}_{4}$ fluxes and total mineral $\mathrm{N}$ concentrations in montane forest soils in Ecuador, suggesting $\mathrm{N}$ limitation on methanotrophic activity (Wolf et al., 2012). While the positive correlation of $\mathrm{NO}_{3}^{-}$with $\mathrm{CH}_{4}$ fluxes may indicate inhibitory effects of nitrification on $\mathrm{CH}_{4}$ consumption, 


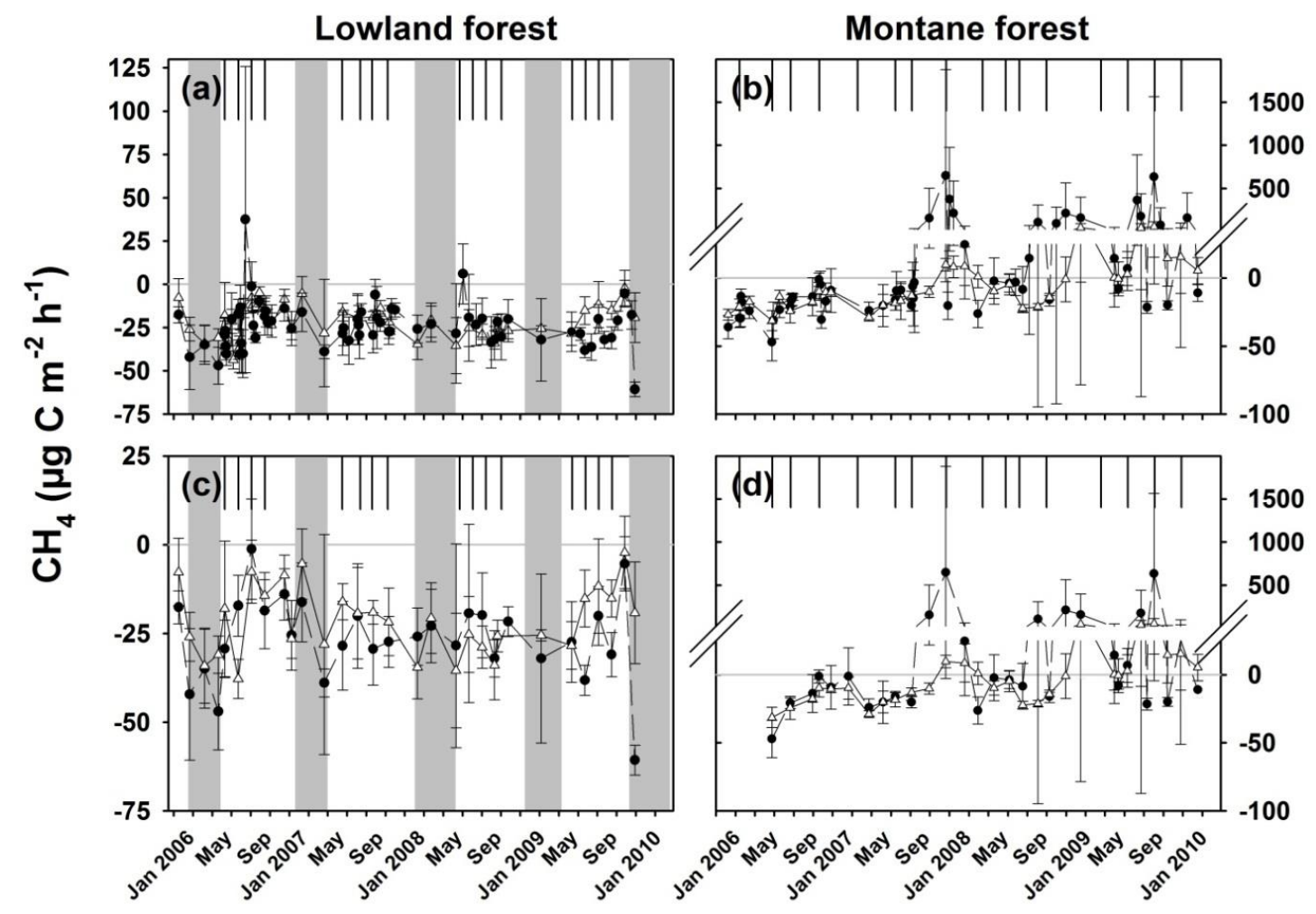

Fig. 3. Mean $( \pm \mathrm{SE}, n=4)$ soil $\mathrm{CH}_{4}-\mathrm{C}$ fluxes from the control $(\triangle)$ and $\mathrm{N}$-addition $(\bullet)$ plots of the lowland forest (a and $\left.\mathbf{c}\right)$ and montane forest (b and d). The black vertical lines indicate dates of $\mathrm{N}$ addition during 9 to $12 \mathrm{yr}$ of treatment in the lowland forest and 1 to $4 \mathrm{yr}$ of treatment in the montane forest; the grey horizontal lines mark the zero flux. The upper panels include all fluxes whereas the lower panels show only the long-term fluxes, which were measured at least six weeks after a $\mathrm{N}$ addition. Grey shadings in (a) and (c) mark the dry seasons.

we think that this is very unlikely since the $\mathrm{NO}_{3}^{-}$concentrations were one to two orders of magnitude smaller than the $\mathrm{NH}_{4}^{+}$concentrations (compare Fig. $2 \mathrm{c}$ and $\mathrm{d}$ and $2 \mathrm{e}$ and $\mathrm{f}$, and note the different scales on the $y$ axis). Furthermore, measurements of gross and net nitrification rates showed very low nitrification activity (Koehler et al., 2009; Corre et al., 2010). Although Bodelier and Laanbroek (2004) suggest that $\mathrm{N}$ limitation of methanotrophic bacteria is less likely at (sub)atmospheric $\mathrm{CH}_{4}$ concentrations in the soil, we had ancillary measurements of the soil-air $\mathrm{CH}_{4}$ concentrations in our montane forest soil that showed $\mathrm{CH}_{4}$ concentrations in this forest soil were occasionally high. These measurements were conducted monthly from October 2008 to January 2010 in three control plots and three $\mathrm{N}$-addition plots for various layers: $0.10 \mathrm{~m}$ above the soil surface, at the interface of the organic layer and mineral soil, at 0.05, 0.20, 0.40, 0.75 and $1.25 \mathrm{~m}$ depths in the mineral soil; we employed the same gas sampling methods described in our earlier study (Koehler et al., 2012). We found that $34 \%$ of 421 observations had $\mathrm{CH}_{4}$ concentrations in the mineral soil higher than the concentration at $0.10 \mathrm{~m}$ above the soil surface of $2.0 \pm 0.1 \mathrm{ppm} \mathrm{CH}_{4}-\mathrm{C}$, particularly during periods of high rainfall and thus high soil water contents. Such high $\mathrm{CH}_{4}$ concentrations in our montane forest soil air may allow for population increases of methanotrophic bacteria which, in turn, may lead to $\mathrm{N}$ limitation on their activity (Bodelier and Laanbroek, 2004).

\subsection{Response of soil $\mathrm{CH}_{4}$ fluxes to $\mathrm{N}$ addition in the lowland and montane forests}

In contrast to the findings from temperate forest soils (Steudler et al., 1989; Brumme and Borken, 1999), tropical pasture soil (Veldkamp et al., 2001) and subtropical forest soil (Zhang et al., 2008), $\mathrm{CH}_{4}$ uptake in our lowland forest soil was not inhibited by chronic $\mathrm{N}$ addition. Instead, the negative correlation of $\mathrm{CH}_{4}$ fluxes with $\mathrm{NO}_{3}^{-}$concentrations in the $\mathrm{N}$-addition plots suggests that increased $\mathrm{NO}_{3}^{-}$ levels in these plots had stimulated $\mathrm{CH}_{4}$ consumption (Bodelier and Laanbroek, 2004) and/or had inhibited $\mathrm{CH}_{4}$ production (Conrad, 1989). The latter is however unlikely because our ancillary measurements of $\mathrm{CH}_{4}$ concentrations at various depths of the mineral soil $(0.05,0.20,0.40,0.75,1.25$ and $2 \mathrm{~m}$ depth) in this lowland forest during the same study years (May 2006-January 2009) showed that $11 \%$ of the observations had higher soil-air $\mathrm{CH}_{4}$ concentrations than the average soil-air $\mathrm{CH}_{4}$ concentrations at a specific depth. These high soil-air $\mathrm{CH}_{4}$ concentrations occurred in all depths of both $\mathrm{N}$-addition and control plots regardless of season, indicating 
Table 3. Compilation of $\mathrm{CH}_{4}-\mathrm{C}$ fluxes $\left(\mathrm{kg} \mathrm{CH}_{4}-\mathrm{Cha}^{-1} \mathrm{yr}^{-1}\right)$ from soils of old-growth (sub)tropical forests, sorted from smallest to largest uptake rates within each elevation category.

\begin{tabular}{|c|c|c|c|c|c|c|c|c|}
\hline Country & $\begin{array}{r}\text { Ele- } \\
\text { vation } \\
(\mathrm{m})\end{array}$ & $\begin{array}{r}\text { Annual } \\
\mathrm{CH}_{4-} \\
\mathrm{C} \text { flux }\end{array}$ & $\begin{array}{l}\text { Annual } \\
\text { rainfall } \\
(\mathrm{mm})\end{array}$ & $\begin{array}{l}\text { Clay } \\
\text { content } \\
(\%)\end{array}$ & $\begin{array}{l}\text { Sand } \\
\text { content } \\
(\%)\end{array}$ & $\begin{array}{l}\text { Organic } \\
\text { layer } \\
\text { thickness* } \\
(\mathrm{cm})\end{array}$ & $\begin{array}{l}\mathrm{N} \text { deposition } \\
\left(\mathrm{kg} \mathrm{Nha}^{-1} \mathrm{yr}^{-1}\right)\end{array}$ & Reference \\
\hline \multicolumn{9}{|c|}{ Sites $<800$ m elevation } \\
\hline Brazil & 120 & -0.55 & 2000 & 80 & 18 & 0 & not reported & Keller et al. (2005) \\
\hline Brazil & 120 & -0.83 & 2000 & 75 & 20 & 0 & not reported & Davidson et al. (2004) \\
\hline China & 720 & -0.93 & 1557 & 54 & 17 & 0 & 18.0 & Fang et al. (2010) \\
\hline Brazil & 100 & -1.57 & 1850 & $80^{*}$ & $15^{*}$ & 0 & not reported & Verchot et al. (2000) \\
\hline Panama & 43 & -1.93 & 2715 & 69 & 7 & 0 & 9.0 & Present study \\
\hline China & 300 & -1.93 & 1564 & 22 & 20 & 0 & 38.0 & Fang et al. (2010) \\
\hline Australia & 50 & -2.35 & 4395 & $30^{*}$ & $60^{*}$ & 0 & not reported & Kiese et al. (2008) \\
\hline Australia & 800 & -2.41 & 1594 & $30^{*}$ & $60^{*}$ & 0 & not reported & Kiese et al. (2008) \\
\hline China & 770 & -2.58 & 1493 & 18 & 59 & 0 & 18.0 & Werner et al. (2006) \\
\hline Brazil & 120 & -2.60 & 2000 & 38 & 60 & 0 & not reported & Keller et al. (2005) \\
\hline Brazil & 100 & -2.74 & 3050 & 32 & 60 & 0 & 8.0 & Sousa Neto et al. (2011) \\
\hline Australia & 50 & -2.94 & 3609 & $60^{*}$ & $20^{*}$ & 0 & not reported & Kiese et al. (2008) \\
\hline Costa Rica & 60 & -3.45 & 4200 & 76 & 20 & 0 & 9.6 & Keller and Reiners (1994) \\
\hline Brazil & 124 & -3.50 & 2200 & $20^{*}$ & $75^{*}$ & 0 & not reported & Steudler et al. (1996) \\
\hline China & 300 & -3.60 & 1927 & 29 & 38 & 0 & 36.0 & Zhang et al. (2008) \\
\hline Brazil & 400 & -4.90 & 3050 & 16 & 67 & 0 & 8.0 & Sousa Neto et al. (2011) \\
\hline \multicolumn{9}{|c|}{ Sites $>800 \mathrm{~m}$ elevation } \\
\hline Panama & 1200 & -0.37 & 5461 & 13 & 61 & 10 & 5.0 & Present study \\
\hline Ecuador & 3000 & -1.06 & 4500 & 17 & 30 & 14 & 4.4 & Wolf et al. (2012) \\
\hline Indonesia & 2470 & -1.45 & not measured & 17 & 59 & 15 & not measured & Purbopuspito et al. (2006) \\
\hline Indonesia & 1190 & -2.45 & 1590 & 12 & 64 & 0 & 2.6 & Purbopuspito et al. (2006) \\
\hline Ecuador & 2000 & -3.10 & 1950 & 18 & 25 & 13 & 2.9 & Wolf et al. (2012) \\
\hline Indonesia & 1800 & -3.32 & not measured & 32 & 51 & 20 & not measured & Purbopuspito et al. (2006) \\
\hline Brazil & 1000 & -4.40 & 2300 & 20 & 57 & 0 & 2.1 & Sousa Neto et al. (2011) \\
\hline Kenya & 1600 & -4.94 & 1662 & 34 & 43 & 0 & not reported & Werner et al. (2007) \\
\hline Ecuador & 1000 & -5.60 & 2230 & 25 & 41 & 4 & 1.5 & Wolf et al. (2012) \\
\hline
\end{tabular}

* Percentages of clay and sand were estimated from the reported soil texture class. If no organic layer was mentioned, we assumed that it was absent (i.e. thickness of $0 \mathrm{~cm}$ ).

that inhibition by high $\mathrm{NO}_{3}^{-}$levels in $\mathrm{N}$ addition plots on $\mathrm{CH}_{4}$ production was unlikely (Koehler et al., 2012). Instead, there were other supporting indications that methanotrophic activity was $\mathrm{N}$ limited aside from the negative correlation of soil $\mathrm{CH}_{4}$ fluxes with $\mathrm{NO}_{3}^{-}$concentrations: soil-air $\mathrm{CH}_{4}$ concentrations and contents (or the total amount of $\mathrm{CH}_{4}$ in a soil-air volume) down to $0.4 \mathrm{~m}$ depth were $30 \%$ lower in $\mathrm{N}$-addition than in control plots, and the minimum $\mathrm{CH}_{4}$ concentration of $552 \pm 42 \mathrm{ppb}$ was reached at shallower depth (already at $0.40 \mathrm{~m}$ ) in N-addition than in control plots (only at $1.25 \mathrm{~m}$ depth) (Koehler et al., 2012). It should be noted that these patterns were not influenced by WFPS because there were no differences in WFPS between control and $\mathrm{N}$-addition plots at all depths. The reason why we did not detect significant differences in soil $\mathrm{CH}_{4}$ fluxes despite stimulated $\mathrm{CH}_{4}$ uptake by chronic $\mathrm{N}$ addition is first due to the large spatial and temporal variations of $\mathrm{CH}_{4}$ fluxes (Fig. $3 \mathrm{a}$ and c). Similar large variability was reported for tropical lowland forest soils and was attributed to production of $\mathrm{CH}_{4}$ by termites or in microsites of anaerobic conditions, and to temporal patterns of rainfall and soil moisture contents (Verchot et al., 2000; Davidson et al., 2004; Koehler et al., 2012). Second, $\mathrm{CH}_{4}$ consumption was also largely limited by gas diffusion as shown by the positive correlation of $\mathrm{CH}_{4}$ fluxes with WFPS (Table 2). Even if $\mathrm{N}$ addition stimulated methanotrophic activity, the supply of $\mathrm{CH}_{4}$ as substrate from the atmosphere to the soil through diffusion did not change, and thus chronic $\mathrm{N}$ addition did not necessarily result in a larger $\mathrm{CH}_{4}$ uptake rate. Stimulation of methanotrophic activity may be explained by a shift in $\mathrm{N}$ nutrition of type II methanotrophic bacteria from energy-demanding $\mathrm{N}_{2}$ fixation to assimilation of soil mineral N (Bodelier and Laanbroek, 2004; Koehler et al., 2012), of which the $\mathrm{NO}_{3}^{-}$concentrations had increased under chronic $\mathrm{N}$ addition (Fig. 2b).

In the montane forest soil, there was also an indication that methanotrophic activity was stimulated by chronic 
$\mathrm{N}$ addition as shown by the negative correlations between $\mathrm{CH}_{4}$ fluxes and $\mathrm{NH}_{4}^{+}$concentrations of the organic layer. However, this $\mathrm{N}$-stimulated methanotrophic activity was masked by the frequent $\mathrm{CH}_{4}$ emissions. The frequent $\mathrm{CH}_{4}$ emissions in this wet montane forest soil indicated the regulation of WFPS of the mineral soil on $\mathrm{CH}_{4}$ fluxes, as was shown by their positive correlation when all $\mathrm{CH}_{4}$ fluxes are included in the statistical analysis (Table 2). WFPS did not only regulate $\mathrm{CH}_{4}$ fluxes through the diffusive limitation of $\mathrm{CH}_{4}$ as substrate for methanotrophs but also through the occurrence of anaerobic conditions for $\mathrm{CH}_{4}$ production. Indeed, the WFPS of this montane forest was high throughout the year (Fig. 1b), and our ancillary measurements of WFPS at various depths in the mineral soil of these plots, conducted monthly during October 2008 to January 2010, showed WFPS between $96 \pm 1 \%$ and $88 \pm 1 \%$ from $0.20 \mathrm{~m}$ down to $1.25 \mathrm{~m}$ depth. Such high WFPS may have favoured $\mathrm{CH}_{4}$ production and thus the frequent $\mathrm{CH}_{4}$ emissions from all eight plots. This was probably the principal reason why we were not able to detect potential differences in $\mathrm{CH}_{4}$ uptake rates between control and $\mathrm{N}$-addition plots despite an indication of $\mathrm{N}$ limitation on $\mathrm{CH}_{4}$ consumption. Exclusion of one pair of control and $\mathrm{N}$-addition plots that strongly dominated the $\mathrm{CH}_{4}$ emissions during our four-year measurements did not change the statistical trend even though the mean $\mathrm{CH}_{4}$ uptake rates in the $\mathrm{N}$-addition plots were seemingly larger than the control plots in all years (Table 1).

\subsection{Consequences of chronic $\mathrm{N}$ deposition on soil $\mathrm{CH}_{4}$ fluxes from tropical forests}

Nine to twelve years of $\mathrm{N}$ addition to a lowland forest and one to four years of $\mathrm{N}$ addition to a montane forest did not affect soil $\mathrm{CH}_{4}$ fluxes, although we found indications that $\mathrm{CH}_{4}$ consumption may have been $\mathrm{N}$ limited at both sites. We proposed the following reasons why such $\mathrm{N}$-stimulated $\mathrm{CH}_{4}$ consumption did not lead to statistically larger $\mathrm{CH}_{4}$ uptake: (1) for the moist, lowland forest soil, this was caused by limitation of $\mathrm{CH}_{4}$ diffusion from the atmosphere into the clayey soils, particularly during the wet season when WFPS was high; (2) for the wet, montane forest soil, this was due to the high WFPS in the mineral soil throughout the year, which may not only limit $\mathrm{CH}_{4}$ diffusion from the atmosphere into the soil but also favours $\mathrm{CH}_{4}$ production; and (3) both forest soils showed large spatial and temporal variations of $\mathrm{CH}_{4}$ fluxes. The lowland forest soil showed occasional but low $\mathrm{CH}_{4}$ emissions whereas the montane forest soil showed more frequent $\mathrm{CH}_{4}$ emissions with a few exceptionally large emissions (Fig. 3). Accordingly, such high $\mathrm{CH}_{4}$ concentrations in the soil provide large amounts of substrate for methanotrophy and favour $\mathrm{N}$ limitation on methanotrophic bacteria (Bodelier and Laanbroek, 2004).
Our results contrast with the only published study about Naddition effects on soil $\mathrm{CH}_{4}$ fluxes from (sub)tropical forests, which was conducted in China, where increasing $\mathrm{N}$ addition rates resulted in decreasing $\mathrm{CH}_{4}$ uptake rates. These results were attributed to several possible causes: high $\mathrm{N}$ status, low $\mathrm{pH}$ values and $\mathrm{Al}$ toxicity (Zhang et al., 2008; Zhang et al., 2011). Although our lowland forest soil also had a high $\mathrm{N}$ status (Corre et al., 2010) and our montane forest soil also had low $\mathrm{pH}$ and high exchangeable $\mathrm{Al}$ (see Sect. 2.2), the differences in site conditions between our sites and this forest in China are that the Chinese site had suffered decades of high $\mathrm{N}$ deposition (Table 3 ) leading to soil $\mathrm{pH}$ values below 4.0, exchangeable $\mathrm{Al}$ of $>400 \mathrm{mg} \mathrm{Al} \mathrm{kg}^{-1}$ even in the control plots, and never emitted $\mathrm{CH}_{4}$ during the first year of measurements. Sub-atmospheric soil $\mathrm{CH}_{4}$ concentrations are possibly prevalent in this Chinese site, and in such conditions methanotrophic activity is less likely to be $\mathrm{N}$ limited (Bodelier and Laanbroek, 2004).

If our explanation for the contrasting effects of $\mathrm{N}$ additions between our study sites and that of Zhang et al. (2008) holds up throughout the tropics, it is unlikely that elevated $\mathrm{N}$ deposition on tropical forests will lead to a rapid reduction in $\mathrm{CH}_{4}$ uptake. We expect that in tropical montane forests, which typically have low $\mathrm{N}$ availability, $\mathrm{N}$ deposition may stimulate $\mathrm{CH}_{4}$ oxidation at sites where occasional $\mathrm{CH}_{4}$ emissions occur or will cause no change in $\mathrm{CH}_{4}$ uptake at sites where no $\mathrm{CH}_{4}$ emissions occur. In tropical lowland forests, which often have a high $\mathrm{N}$ availability, $\mathrm{N}$ deposition only appears to inhibit $\mathrm{CH}_{4}$ uptake if soil $\mathrm{pH}$ values have become so low that considerable Al toxicity occurs. In other situations, it seems more likely that $\mathrm{N}$ deposition will not affect $\mathrm{CH}_{4}$ fluxes or may even stimulate $\mathrm{CH}_{4}$ uptake. Whether $\mathrm{N}$ additions to tropical forests with $\mathrm{N}$-limited methanotrophic activity can indeed stimulate soil $\mathrm{CH}_{4}$ uptake remains to be seen. The most likely time when $\mathrm{CH}_{4}$ uptake may be stimulated by $\mathrm{N}$ additions is during dry periods/seasons when $\mathrm{CH}_{4}$ supply from the atmosphere is not or less limited by gas diffusion. The most likely place where $\mathrm{CH}_{4}$ uptake may be stimulated by $\mathrm{N}$ addition is in forests with a strong seasonal rainfall where occasional $\mathrm{CH}_{4}$ emissions occur during the rainy season and strong uptake occurs during the dry season.

Acknowledgements. We thank S. Joseph Wright, one of the PIs of the Gigante nutrient manipulation experiment, for hosting our study, valuable discussions and support; Oliver van Straaten for discussions and reading an earlier version of this manuscript; James Dalling for his help during the selection of the montane forest site; Rodolfo Rojas, Carlos Sanchez, Erick Diaz, Ignacio Del Cid, Olivier Gonzalez, Omar Hernandez and Rufino Gonzalez for their dedicated assistance during field measurements; Norman Loftfield, Milton Garcia and Jaime Florez for their help with the equipment; the Smithsonian Tropical Research Institute and ANAM, Panama, for extending excellent logistical and technical support; the laboratory staff of Soil Science of Tropical and Subtropical Ecosystems, for their assistance with laboratory analyses, and the three referees 
for their thorough and helpful reviews. M. D. Corre acknowledges funding from the Robert Bosch Foundation (Germany) for her independent research group NITROF, and from the Deutsche Forschungsgemeinschaft (Co 749/1-1). B. Koehler acknowledges further funding by the Swedish Research Council for Environment, Agricultural Sciences and Spatial Planning and from Erwin Zehe at the Karlsruhe Institute of Technology, Germany.

This Open Access Publication is funded

by the University of Göttingen.

Edited by: Z. Jia

\section{References}

Adamek, M., Corre, M. D., and Hoelscher, D.: Early effect of elevated nitrogen input on above-ground net primary production of a lower montane rain forest, Panama, J. Trop. Ecol., 25, 637-647, doi:10.1017/S0266467409990253, 2009.

Adamek, M., Corre, M. D., and Hoelscher, D.: Responses of fine roots to experimental nitrogen addition in a tropical lower montane rain forest, Panama, J. Trop. Ecol., 27, 73-81, doi:10.1017/S0266467410000507, 2011.

Arnold, J., Corre, M. D., and Veldkamp, E.: Cold storage and laboratory incubation of intact soil cores do not reflect in-situ nitrogen cycling rates of tropical forest soils, Soil Biol. Biochem., 40, 2480-2483, doi:10.1016/j.soilbio.2008.06.001, 2008.

Bédard, C. and Knowles, R.: Physiology, biochemistry, and specific inhibitors of $\mathrm{CH}_{4}, \mathrm{NH}_{4}^{+}$, and $\mathrm{CO}$ oxidation by methanotrophs and nitrifiers, Microbiol. Rev., 53, 68-84, 1989.

Bender, M. and Conrad, R.: Effect of $\mathrm{CH}_{4}$ concentrations and soil conditions on the induction of $\mathrm{CH}_{4}$ oxidation activity, Soil Biol. Biochem., 27, 1517-1527, doi:10.1016/0038-0717(95)00104-M, 1995.

Bodelier, P. L., Roslev, P., Henckel, T., and Frenzel, P.: Stimulation by ammonium-based fertilizers of methane oxidation in soil around rice roots, Nature, 403, 421-424, doi:10.1038/35000193, 2000.

Bodelier, P. L. E. and Laanbroek, H. J.: Nitrogen as a regulatory factor of methane oxidation in soils and sediments, FEMS Microb. Ecol., 47, 265-277, doi:10.1016/s0168-6496(03)00304-0, 2004.

Breuer, L., Kiese, R., and Butterbach-Bahl, K.: Temperature and moisture effects on nitrification rates in tropical rain-forest soils, Soil Sci. Soc. Am. J., 66, 834-844, 2002.

Brumme, R. and Borken, W.: Site variation in methane oxidation as affected by atmospheric deposition and type of temperate forest ecosystem, Global Biogeochem. Cy., 13, 493-501, doi:10.1029/1998GB900017, 1999.

Conrad, R.: Control of methane production in terrestrial ecosystems, in: Exchange of trace gases between terrestrial ecosystems and the atmosphere, edited by: Andreae, M. O. and Schimel, D. S., Wiley, Chichester, UK, 39-58, 1989.

Corre, M. D., Veldkamp, E., Arnold, J., and Wright, S. J.: Impact of elevated $\mathrm{N}$ input on soil $\mathrm{N}$ cycling and losses in old-growth lowland and montane forests in Panama, Ecology, 91, 1715-1729, doi:10.1890/09-0274.1, 2010.

Crawley, M. J.: The R book, John Wiley \& Sons Ltd, Chichester, UK, 2009.
Crill, P. M., Martikainen, P. J., Nykanen, H., and Silvola, J.: Temperature and $\mathrm{N}$ fertilization effects on methane oxidation in a drained peatland soil, Soil Biol. Biochem., 26, 1331-1339, doi:10.1016/0038-0717(94)90214-3, 1994.

Davidson, E. A., Ishida, F. Y., and Nepstad, D. C.: Effects of an experimental drought on soil emissions of carbon dioxide, methane, nitrous oxide, and nitric oxide in a moist tropical forest, Glob. Change Biol., 10, 718-730, doi:10.1111/j.13652486.2004.00762.x, 2004.

Denman, K. L., Brasseur, G., Chidthaisong, A., Ciais, P., Cox, P. M., Dickinson, R. E., Hauglustaine, D., Heinze, C., Holland, E., Jacob, D., Lohmann, U., Ramachandran, S., Dias, P. L. d. S., Wofsy, S. C., and Zhang, X.: Couplings Between Changes in the Climate System and Biogeochemistry, in: Climate Change 2007: The Physical Science Basis. Contribution of Working Group I to the Fourth Assessment Report of the Intergovernmental Panel on Climate Change, edited by: Solomon, S., Qin, D., Manning, M., Chen, Z., Marquis, M., Averyt, K. B., Tignor, M., and Miller, H. L., Cambridge University Press, Cambridge, United Kingdom and New York, NY, USA, 2007.

Dutaur, L. and Verchot, L. V.: A global inventory of the soil $\mathrm{CH}_{4}$ sink, Global Biogeochem. Cy., 21, GB4013, doi:10.1029/2006gb002734, 2007.

Fang, H. J., Yu, G. R., Cheng, S. L., Zhu, T. H., Wang, Y. S., Yan, J. H., Wang, M., Cao, M., and Zhou, M.: Effects of multiple environmental factors on $\mathrm{CO}_{2}$ emission and $\mathrm{CH}_{4}$ uptake from oldgrowth forest soils, Biogeosciences, 7, 395-407, doi:10.5194/bg7-395-2010, 2010.

Frankenberg, C., Bergamaschi, P., Butz, A., Houweling, S., Meirink, J. F., Notholt, J., Petersen, A. K., Schrijver, H., Warneke, T., and Aben, I.: Tropical methane emissions: A revised view from SCIAMACHY onboard ENVISAT, Geophys. Res. Lett., 35, L15811, doi:10.1029/2008g1034300, 2008.

Galloway, J. N., Townsend, A. R., Erisman, J. W., Bekunda, M., Cai, Z., Freney, J. R., Martinelli, L. A., Seitzinger, S. P., and Sutton, M. A.: Transformation of the nitrogen cycle: recent trends, questions, and potential solutions, Science, 320, 889-892, doi:10.1126/science.1136674, 2008.

Hanson, R. S. and Hanson, T. E.: Methanotrophic bacteria, Microbiol. Rev., 60, 439-471, 1996.

Hietz, P., Turner, B. L., Wanek, W., Richter, A., Nock, C. A., and Wright, S. J.: Long-term change in the nitrogen cycle of tropical forests, Science, 334, 664-666, doi:10.1126/science.1211979, 2011.

Hillel, D.: Environmental soil physics, Academic Press, San Diego, California, USA, 771 pp., 1998.

Keller, M. and Matson, P. A.: Biosphere-Atmosphere exchange of trace gases in the tropics: evaluating the effects of land use changes, in: Global Atmospheric-Biospheric Chemistry, edited by: Prinn, R. G., Plenum Press, New York, 103-117, 1994.

Keller, M. and Reiners, W. A.: Soil-atmosphere exchange of nitrous oxide, nitric oxide and methane under secondary succession of pasture to forest in the Atlantic lowlands of Costa Rica, Global Biogeochem. Cy., 8, 399-409, doi:10.1029/94GB01660, 1994.

Keller, M., Varner, R., Dias, J. D., Silva, H., Crill, P., and de Oliveira, R. C.: Soil-atmosphere exchange of nitrous oxide, nitric oxide, methane, and carbon dioxide in logged and undisturbed forest in the Tapajos National Forest, Brazil, Earth Interact., 9, 1-28, doi:10.1175/EI125.1, 2005. 
Kiese, R., Hewett, B., Graham, A., and Butterbach-Bahl, K.: Seasonal variability of $\mathrm{N}_{2} \mathrm{O}$ and $\mathrm{CH}_{4}$ uptake by tropical rainforest soils of Queensland, Australia, Global Biogeochem. Cy., 17, 1043, doi:10.1029/2002GB002014, 2003.

Kiese, R., Wochele, S., and Butterbach-Bahl, K.: Site specific and regional estimates of methane uptake by tropical rainforest soils in north eastern Australia, Plant Soil, 309, 211-226, doi:10.1007/s11104-008-9545-0, 2008.

Klüber, H. D. and Conrad, R.: Effects of nitrate, nitrite, NO and $\mathrm{N}_{2} \mathrm{O}$ on methanogenesis and other redox processes in anoxic rice field soil, FEMS Microb. Ecol., 25, 301-318, doi:10.1111/j.1574-6941.1998.tb00482.x, 1998.

Koehler, B., Corre, M. D., Veldkamp, E., Wullaert, H., and Wright, S. J.: Immediate and long-term nitrogen oxide emissions from tropical forest soils exposed to elevated nitrogen input, Glob. Change Biol., 15, 2049-2066, doi:10.1111/j.13652486.2008.01826.x, 2009.

Koehler, B., Corre, M. D., Steger, K., Well, R., Zehe, E., Sueta, J. P., and Veldkamp, E.: An in-depth look into a tropical lowland forest soil: nitrogen-addition effects on the contents of $\mathrm{N}_{2} \mathrm{O}$, $\mathrm{CO}_{2}$ and $\mathrm{CH}_{4}$ and $\mathrm{N}_{2} \mathrm{O}$ isotopic signatures down to 2-m depth, Biogeochemistry, 111, 695-713, doi:10.1007/s10533-012-97116, 2012.

Linn, D. and Doran, J.: Effect of water-filled pore space on carbon dioxide and nitrous oxide production in tilled and nontilled soils, Soil Sci. Soc. Am. J., 48, 1267-1272, 1984.

Livingston, G. P., Hutchinson, G. L., and Spartalian, K.: Trace gas emission in chambers, Soil Sci. Soc. Am. J., 70, 1459-1469, doi:10.2136/sssaj2005.0322, 2006.

Loftfield, N., Flessa, H., Augustin, J., and Beese, F.: Automated gas chromatographic system for rapid analysis of the atmospheric trace gases methane, carbon dioxide, and nitrous oxide, J. Environ. Qual., 26, 560-564, 1997.

Martinson, G. O., Werner, F. A., Scherber, C., Conrad, R., Corre, M. D., Flessa, H., Wolf, K., Klose, M., Gradstein, S. R., and Veldkamp, E.: Methane emissions from tank bromeliads in neotropical forests, Nat. Geosci., 3, 766-769, doi:10.1038/Ngeo980, 2010.

Mosier, A. R., Parton, W. J., Valentine, D. W., Ojima, D. S., Schimel, D. S., and Delgado, J. A.: $\mathrm{CH}_{4}$ and $\mathrm{N}_{2} \mathrm{O}$ fluxes in the Colorado shortgrass steppe: 1. Impact of landscape and nitrogen addition, Global Biogeochem. Cy., 10, 387-399, doi:10.1029/96GB01454, 1996.

Nesbit, S. P. and Breitenbeck, G. A.: A laboratory study of factors influencing methane uptake by soils, Agr. Ecosyst. Environ., 41, 39-54, doi:10.1016/0167-8809(92)90178-E, 1992.

Purbopuspito, J., Veldkamp, E., Brumme, R., and Murdiyarso, D.: Trace gas fluxes and nitrogen cycling along an elevation sequence of tropical montane forests in Central Sulawesi, Indonesia, Global Biogeochem. Cy., 20, GB3010, doi:10.1029/2005GB002516, 2006.

R Development Core Team: R: A language and environment for statistical computing, R Foundation for Statistical Computing, Vienna, Austria, 2011.

Reeburgh, W.: Global methane biogeochemistry, in: Treatise on geochemistry, edited by: Keeling, R. F., Holland, H., and Turekian, K., Elsevier, Oxford, UK, 65-89, 2003.

Sousa Neto, E., Carmo, J. B., Keller, M., Martins, S. C., Alves, L. F., Vieira, S. A., Piccolo, M. C., Camargo, P., Couto, H. T. Z., Joly,
C. A., and Martinelli, L. A.: Soil-atmosphere exchange of nitrous oxide, methane and carbon dioxide in a gradient of elevation in the coastal Brazilian Atlantic forest, Biogeosciences, 8, 733-742, doi:10.5194/bg-8-733-2011, 2011.

Steudler, P. A., Bowden, R. D., Melillo, J. M., and Aber, J. D.: Influence of nitrogen fertilization on methane uptake in temperate forest soils, Nature, 341, 314-316, doi:10.1038/341314a0, 1989.

Steudler, P. A., Melillo, J. M., Feigl, B. J., Neill, C., Piccolo, M. C., and Cerri, C. C.: Consequences of forest-to-pasture conversion on $\mathrm{CH}_{4}$ fluxes in the Brazilian Amazon Basin, J. Geophys. Res.Atmos., 101, 18547-18554, doi:10.1029/96JD01551, 1996.

Veldkamp, E., Weitz, A. M., and Keller, M.: Management effects on methane fluxes in humid tropical pasture soils, Soil Biol. Biochem., 33, 1493-1499, doi:10.1016/S0038-0717(01)000608, 2001.

Verchot, L. V., Davidson, E. A., Cattanio, J. H., and Ackerman, I. L.: Land-use change and biogeochemical controls of methane fluxes in soils of eastern Amazonia, Ecosystems, 3, 41-56, doi:10.1007/s100210000009, 2000.

Vitousek, P. M., Aber, J. D., Howarth, R. W., Likens, G. E., Matson, P. A., Schindler, D. W., Schlesinger, W. H., and Tilman, D. G.: Human alteration of the global nitrogen cycle - sources and consequences [review], Ecol. Appl., 7, 737-750, doi:10.1890/10510761(1997)007[0737:HAOTGN]2.0.CO;2, 1997.

Wagner, S. W., Reicosky, D. C., and Alessi, R. S.: Regression models for calculating gas fluxes measured with a closed chamber, Agronom. J., 89, 279-284, 1997.

Werner, C., Zheng, X., Tang, J., Xie, B., Liu, C., Kiese, R., and Butterbach-Bahl, K.: $\mathrm{N}_{2} \mathrm{O}, \mathrm{CH}_{4}$ and $\mathrm{CO}_{2}$ emissions from seasonal tropical rainforests and a rubber plantation in Southwest China, Plant Soil, 289, 335-353, doi:10.1007/s11104-006-9143y, 2006.

Werner, C., Kiese, R., and Butterbach-Bahl, K.: Soil-atmosphere exchange of $\mathrm{N}_{2} \mathrm{O}, \mathrm{CH}_{4}$, and $\mathrm{CO}_{2}$ and controlling environmental factors for tropical rain forest sites in western Kenya, J. Geophys. Res., 112, D03308, doi:10.1029/2006jd007388, 2007.

Wolf, K., Flessa, H., and Veldkamp, E.: Atmospheric methane uptake by tropical montane forest soils and the contribution of organic layers, Biogeochemistry, 111, 469-483, doi:10.1007/s10533-011-9681-0, 2012.

Wright, S. J., Yavitt, J. B., Wurzburger, N., Turner, B. L., Tanner, E. V. J., Sayer, E. J., Santiago, L. S., Kaspari, M., Hedin, L. O., Harms, K. E., Garcia, M. N., and Corre, M. D.: Potassium, phosphorus or nitrogen limit root allocation, tree growth and litter production in a lowland tropical forest, Ecology, 92, 1616-1625, doi:10.1890/10-1558.1, 2011.

Yavitt, J. B., Fahey, T. J., and Simmons, J. A.: Methane and Carbon Dioxide Dynamics in a Northern Hardwood Ecosystem, Soil Sci. Soc. Am. J., 59, 796-804, doi:10.2136/sssaj1995.03615995005900030023x, 1995.

Zhang, T., Zhu, W., Mo, J., Liu, L., and Dong, S.: Increased phosphorus availability mitigates the inhibition of nitrogen deposition on $\mathrm{CH}_{4}$ uptake in an old-growth tropical forest, southern China, Biogeosciences, 8, 2805-2813, doi:10.5194/bg-8-28052011, 2011.

Zhang, W., Mo, J., Zhou, G., Gundersen, P., Fang, Y., Lu, X., Zhang, T., and Dong, S.: Methane uptake responses to nitrogen deposition in three tropical forests in southern China, J. Geophys. Res., 113, D11116, doi:10.1029/2007jd009195, 2008. 